\title{
Whey microfiltration performance: influence of protein concentration by ultrafiltration and of physicochemical pretreatment
}

\author{
A Pierre, Y Le Graet, G Daufin, F Michel, G Gésan
}

Laboratoire de Recherches de Technologie Laitière, INRA, 65, rue de St-Brieuc, 35042 Rennes, France

(Received 24 June 1993; accepted 24 September 1993)

\begin{abstract}
Summary - Microfiltration with membranes of $0.2 \mu \mathrm{m}$ pore size was used to clarify and defat whey previously ultrafiltered at various volume concentration ratios (VCR, 1-5.5). Physicochemical pretreatment of whey combining calcium addition (in order to reach a final concentration in the range $\left.1.3-3.3 \mathrm{~g} \cdot \mathrm{kg}^{-1}\right), \mathrm{pH}$ increase to 7.3 and a heat treatment $\left(60^{\circ} \mathrm{C}, 10 \mathrm{~min}\right)$ were carried out. The efficiency of microfiltration, performed at a constant permeation flux, was compared with centrifugation. Pretreatment of retentate concentrated to a VCR of 5.5 , led to poor hydraulic performance: a continuous increase in transmembrane pressure (TP) over the whole run ( $60 \mathrm{~min}$ ) from 0.05 to $0.15 \mathrm{MPa}$ brought evidence of rapid membrane fouling. A low total nitrogen matter recovery (TNMr) of 0.41 was obtained. Pretreatment of VCR 2.5 and VCR 4.0 retentates allowed higher TNMr $(0.65)$ and better hydraulic performance, ie slower TP increase to be obtained. With no physicochemical pretreatment, VCR 2.5-4.0-5.5 retentates led to improved hydraulic performance and higher $\operatorname{TNMr}(0.90)$.
\end{abstract}

whey / microfiltration / pretreatment / permeation / performance

Résumé - Optimisation de la microfiltration du lactosérum. Influence de la concentration par ultrafiltration et des prétraitements physicochimiques de clarification. Un lactosérum préalablement ultrafiltré jusqu'à des facteurs de concentration volumiques (FCV) de 2,5; 4,0;5,5 a été microfiltré avec une membrane ayant une taille moyenne de pores de $0,2 \mu \mathrm{m}$. Un prétraitement physicochimique de clarification était effectué dans certains essais (addition du calcium jusqu'à une teneur finale de 1,3 à $3,3 \mathrm{~g} \cdot \mathrm{kg}^{-1}$, augmentation du pH jusqu'à 7,3 suivie d'un traitement thermique à $60^{\circ} \mathrm{C}$ pendant $10 \mathrm{~min}$ ). Les performances hydrauliques de microfiltration et les taux de perméation des constituants du lactosérum ont été étudiés sur une installation fonctionnant à flux de perméation constant. Le prétraitement appliqué à un lactosérum à FCV 5,5 conduit à des performances hydrauliques faibles : une augmentation continue de la pression transmembranaire pendant toute la durée de l'essai $(60 \mathrm{~min})$ de 0,05 à $0,15 \mathrm{MPa}$ est un indice du colmatage rapide de la membrane. Le rendement en matière azotée totale (MAT) est également bas : 0,41 . Le prétraitement appliqué au lactosérum à FCV 2,5 ou 4,0 conduit à des rendements en MAT plus élevés $(0,65)$ et à de meilleures performances hydrauliques. C'est en l'absence de prétraitement que les 3 types de lactosérum (FCV 
$2,5 ; 4,0 ; 5,5)$ ont donné les meilleures performances hydrauliques et les rendements en MAT les plus élevés $(0,90)$.

lactosérum / microfiltration / prétraitement / perméation / performance

\section{INTRODUCTION}

Clarification of whey is currently performed in order to remove constituents involved in membrane fouling and susceptible to interfere with subsequent purification of proteins. Clarification includes 2 steps: precipitation and separation of the formed precipitate.

Precipitation is achieved by manipulating the physicochemical equilibria between calcium and phosphate, either by reducing ionic strength (de Wit et al, 1978), or by adding calcium in association with a heat treatment. This process, also called thermal Ca-treatment, allows the formation of insoluble complexes between $\mathrm{Ca}$ and biological material (Lee and Merson, 1976). The feasibility of this process to all kinds of wheys was demonstrated by Fauquant et al (1985a, b) and Maubois et al (1987).

Three technologies have been proposed for separating the precipitate: decantation (de Wit et al, 1978); centrifugation (CF) (Wasen and Lehmann, 1989); and microfiltration (MF) (Maubois et al, 1987). The feasibility of the third was demonstrated by Baumy et al (1990) and by Maugas and Daufin (1992). Retention of precipitate by different pore-size MF membranes was compared and found suitable when the pore size was lower than $0.6 \mu \mathrm{m}$ in average diameter (Rinn et al, 1990; Pearce et al, 1992). Large daily variations in the MF fluxes of an industrial plant were reported by Gésan et al (1993a), who were able to correlate them with efficiency of the membrane cleaning, daily variations of whey physicochemical characteristics and the MF operating parameters.
In a previous study (Pierre et al, 1992), the influence on protein and calcium contents of whey, temperature, time and $\mathrm{pH}$ of the applied heat treatment was tested in order to optimize clarification but in these experiments only CF was used for separating the precipitated fraction.

The objective of the current work was to compare how the efficiency of whey fractionation is influenced by the separation technology used, CF or MF, with regards to the physicochemical pretreatment $(\mathrm{Ca}$ concentration, $\mathrm{pH}$ and heating time/ temperature) applied to whey previously concentrated by ultrafiltration (UF).

\section{MATERIALS AND METHODS}

\section{Experimental rig}

The MF rig used was described by Daufin et al (1993). It was equipped with M14 Carbosep membranes (Techsep, Miribel, France) with an average pore diameter of $0.14 \mu \mathrm{m}$ and a membrane area of $2.26 \times 10^{-2} \mathrm{~m}^{2}$. MF of the feeds described below was performed for $60 \mathrm{~min}$ at constant tangential flow velocity $(6.00 \pm 0.05$ $\left.\mathrm{m} \cdot \mathrm{s}^{-1}\right)$, temperature $\left(50.0 \pm 0.1^{\circ} \mathrm{C}\right)$ and flux $\left(60.0 \pm 0.5 \mathrm{l} \cdot \mathrm{h}^{-1} \cdot \mathrm{m}^{-2}\right)$.

\section{Feeds}

The chemical composition of the feeds studied in this work is given in table I. These were issued from sweet whey skimmed and filtered (20 $\mu \mathrm{m})$ produced by an emmental cheese plant (ULN, Montauban-de-Bretagne, France). UF until a VCR of $2.5,4.0$ and 5.5 was performed as 
Table I. Microfiltration of retentates. Composition of initial retentates (R) and microfiltrates (MF). Microfiltration des rétentats. Composition des rétentats initiaux $(R)$ et des microfiltrats (MF).

\begin{tabular}{|c|c|c|c|c|c|c|c|c|}
\hline \multirow{2}{*}{$\begin{array}{l}\text { Run } \\
N^{\circ}\end{array}$} & \multirow[t]{2}{*}{ Retentate } & \multirow[t]{2}{*}{ Product } & \multirow[t]{2}{*}{$O D$} & \multirow[t]{2}{*}{$p H$} & $\mathrm{Ca}$ & $P$ & TNM & $T N M r$ \\
\hline & & & & & \multicolumn{4}{|c|}{$g \cdot \mathrm{kg}^{-1}$} \\
\hline & $\mathrm{R}_{2.5}$ & $\mathrm{R}$ & 1.300 & 6.7 & 0.392 & 0.455 & 18.7 & 1.00 \\
\hline 1 & $\mathrm{R}_{2.5}$ & $\mathrm{MF}$ & 0.010 & 6.8 & 0.302 & 0.393 & 16.5 & 0.88 \\
\hline $2-3$ & $R_{2.5-1.3}$ & $\mathrm{MF}^{*}$ & 0.013 & 7.3 & 0.621 & 0.130 & 12.3 & 0.66 \\
\hline 4 & $R_{2.5-3.3}$ & MF & 0.012 & 7.0 & 2.408 & 0.102 & 12.1 & 0.65 \\
\hline & $\mathrm{R}_{4.0}$ & $\mathrm{R}$ & 1.900 & 6.7 & 0.453 & 0.507 & 28.9 & 1.00 \\
\hline $5-6-7$ & $R_{4.0-2.3}$ & $\mathrm{MF}^{\star \star}$ & 0.010 & 7.1 & 1.386 & 0.118 & 18.7 & 0.65 \\
\hline & $R_{5.5}$ & $R$ & 2.200 & 6.7 & 0.498 & 0.548 & 38.9 & 1.00 \\
\hline 8 & $\mathrm{R}_{5.5}$ & MF & 0.034 & 6.7 & 0.450 & 0.469 & 32.4 & 0.83 \\
\hline 9 & $R_{5.5-1.3}$ & MF & 0.048 & 7.2 & 0.615 & 0.191 & 15.8 & 0.41 \\
\hline 10 & $R_{5.5-3.3}$ & MF & 0.041 & 6.9 & 2.280 & 0.129 & 16.3 & 0.42 \\
\hline SE & & & - & - & 0.003 & 0.003 & 0.1 & 0.01 \\
\hline
\end{tabular}

- Mean of 2; "* mean of 3; SE: standard error; TNM: total nitrogen matter; TNMr: total nitrogen matter recovery; OD: optical density.

$S E=$ erreur expérimentale.

described by Pierre et al (1992). UF retentates were frozen until experimentation.

Pretreatment of the UF retentates was carried out according to Pierre et al (1992). Calcium content was adjusted to the range 1.3-3.3 $\mathrm{g} \cdot \mathrm{kg}^{-1}$ through the addition of a $4 \mathrm{~mol} \cdot \mathrm{l}^{-1} \mathrm{CaCl}_{2}$ solution in UF retentates at $16^{\circ} \mathrm{C}$. The $\mathrm{pH}$ was then increased to 7.3 with $5 \mathrm{~mol} \cdot \mathrm{I}^{-1} \mathrm{NaOH}$; the temperature was raised to $60^{\circ} \mathrm{C}$ over $3 \mathrm{~min}$ and held for $10 \mathrm{~min}$. When no calcium was added, the $\mathrm{pH}$ was left at its original value. The precipitate was separated by either CF $(2000 \mathrm{~g}$, $15 \mathrm{~min}, 30^{\circ} \mathrm{C}$ ) with a Heraeus equipment (Osterode, Germany) or MF. Supernatant and microfiltrate samples were collected for analysis.

The nomenclature of feeds $R_{x-y}$ was as follows. $R$ is the UF whey retentate; $x$ is its VCR achieved by UF; and $y$ is the calcium level used for its pretreatment, if any. For example, $R_{2.5-1.3}$ was a retentate at VCR 2.5 , pretreated with calcium to a level $1.3 \mathrm{~g} \cdot \mathrm{kg}^{-1}$.

Ten MF experiments were performed, combining VCR and the amount of calcium as shown in table I. One combination was tested in
3 replicates for the assessment of experimental error (standard error $=\mathrm{SE}$ ). The order of performing trials was randomized to minimize experimental bias.

\section{Calculations}

Flux and transmembrane pressure (TP) measured during the MF runs, and pure water flux, before and after MF, allowed the hydraulic resistances to be calculated (membrane $R_{m}$; total fouling $R_{f}$; reversible fouling $R_{r}$; irreversible fouling $R_{i f}$ ) (Gésan et al, 1993b). The relative error for each hydraulic resistance $(\Delta R / R)$ was assessed as $<5 \%$. Results were reported as normalized fouling resistance: $R / R_{m}$

The mean pore size estimation $\left(r_{t}\right)$ after a whey retentate MF run of time $t$, was calculated from Poiseuille's law as follows:

$$
\frac{\mathrm{TP}_{t}}{\mathrm{TP}_{w}}=\left(\frac{r_{m}{ }^{4}}{r_{t}}\right)
$$


where $\mathrm{TP}_{t}$ and $\mathrm{TP}_{w}$ are the transmembrane pressure, after $t \mathrm{~min}$ of whey retentate MF and during water flux $\left(\mathrm{J}_{w}\right)$, respectively, assessed at the same flux, $J=60 \mathrm{l} \cdot \mathrm{h}^{-1} \cdot \mathrm{m}^{-2} ; r_{m}$ the clean membrane pore radius is $100 \mathrm{~nm}$ (nominal supplier figure). The size of particles in whey retentate was calculated from experimental retention TR according to Ferry's law:

$$
T R=\left[1-\left(1-\frac{a}{r}\right)\right]^{2}
$$

where $a$ is the particle radius to be determined.

TR was obtained from concentration of the constituents in initial whey retentate $\left(C_{r}\right)$ and in whey permeate $\left(C_{p}\right)$ :

$$
\mathrm{TR}=\frac{C_{r}-C_{p}}{C_{r}}
$$

\section{Operating procedure}

Before MF of the feeds, membrane cleaning was carried out with solutions at $50^{\circ} \mathrm{C}$ and retentate pressure $0.2 \mathrm{MPa}$ : i) $\mathrm{HNO}_{3} 0.06 \mathrm{~mol} \cdot \mathrm{F}^{-1}$ for $45 \mathrm{~min}$; ii) filtered water rinsing; iii) $\mathrm{NaOCl}_{3}$ $1000 \mathrm{mg} \cdot \mathrm{H}^{-1} \mathrm{Cl}_{2}, \mathrm{pH} 11$, for $30 \mathrm{~min}$; iv) filtered water rinsing. Pure water flux was measured at constant transmembrane pressure $\mathrm{TP}_{w}=0.1$ $\mathrm{MPa}$, before, $\mathrm{J}_{w}$ and after, $\mathrm{J}_{w}$ the 60-min MF run to assess the hydraulic resistance of clean membrane and fouled membrane. For the MF trials, the flux was gradually increased over 6 $\mathrm{min}$ at a rate of $10 \mathrm{l} \cdot \mathrm{h}^{-1} \cdot \mathrm{min}^{-1}$ until a steadystate flux of $60 \mathrm{l} \cdot \mathrm{h}^{-1} \cdot \mathrm{m}^{-2}$ was achieved. In all experiments, thermal equilibrium was first achieved with the rig full of water $\left(2 \mathrm{~m} \cdot \mathrm{s}^{-1}, 0.2\right.$ $\mathrm{MPa}$ ). Water was then pushed out of the rig by the fluid to be microfiltered. Tangential flow rate and then flux were set to their steady-state values.

\section{Chemical analysis}

The qualitative composition of the proteinic fraction of samples was determined by electrophoresis on gradient polyacrylamide gels, $T=4-$ $30 \%$ (Pharmacia, Uppsala, Sweden) under denaturing and native conditions. The electropho- resis buffer and sample preparation were as described by Andrews (1983).

Lactose and total nitrogen matter (TNM) were measured by IR analysis (Dairy Lab, Multispec, York, UK). Non-protein nitrogen (NPN) was according to Rowland (1938). Individual proteins, ie $\alpha$-lactalbumin (ala), $\beta$-lactoglobulin ( $\beta \mathrm{lg})$ and caseinomacropeptide (CMP) were simultaneously quantified by gel filtration HPLC (SP 8800, Spectra Physics Analytical, San Jose, CA, USA) using a 30-cm TSK SW $2000 \mathrm{DX}$ column (Supelco, Bellefonte, USA) and 30\% acetonitrile in water $(\mathrm{v} / \mathrm{v})$, adjusted to $0.1 \%$ in trifluoroacetic acid, as a solvent (Efstathiu $T$, personal communication). The detection was at $215 \mathrm{~nm}$.

The experimental TNM recovery (TNMr) was estimated as the ratio of TNM in the microfiltrate, at $60 \mathrm{~min}$ MF or in the supernatant, to the TNM of the initial whey retentate. The maximum TNM in microfiltrate and supernatant was estimated from initial whey retentate TNM minus the content of the constituents wholly retained by the membrane as determined by electrophoresis. The level of these retained constituents was quantified from mean values reported for milk by Walstra and Jenness (1984). This calculation accounted for neither membrane fouling nor sieving mechanisms related to relative size of molecules and pores.

Calcium was determined by atomic absorption spectrophotometry (Varian, Palo Alto, CA, USA); phosphorus according to FIL-IDF $n^{\circ} 33 B$ (1982) and chloride by conductivity with an $\mathrm{Ag}$ electrode (chloride analyzer 926-Ciba Corning Diagnostics, Halstead, UK) so as to determine dilution and allow correction for permeate concentration.

The total lipids were extracted with $80 \mathrm{ml}$ methanol/chloroform (2:1 v/v) according to Folch et al (1957), applied on a glass column containing the freeze-dried sample (corresponding to $50 \mathrm{ml}$ liquid whey), mixed with $10 \mathrm{~g}$ celite. Chloroform was added to the collected fraction at $33 \%(\mathrm{v} / \mathrm{v})$, and then, water, at $60 \%$ of the actual volume. After mixing and standing overnight, the lower solvent phase was collected, evaporated and total lipids estimated by weighing. These lipids, solubilized in chloroform, were analyzed by HPLC for their content in phospholipids (Leseigneur et al, 1989; Surel, 1993). The optical density $(O D)$ of whey was measured at $600 \mathrm{~nm}$, as an estimation of turbidity (Spectrophotometer DU 62 , Beckman I, Fullerton, USA). 
The aggregate size in pretreated retentates was measured using an optical microscope (Wild Instruments, Heerbrugg, Switzerland) equipped with an ocular micrometer (magnification $x 400$ ). Colloidal particles in retentates, supernatants and microfiltrates $(<2 \mu \mathrm{m}$ in size), were measured by quasi-elastic light diffusion on a Coulter N4D apparatus (Coultronics, Amherst, MA, USA), with a $90^{\circ}$ angle for the incident light. The samples were diluted in water. The populations are expressed in weight percentage.

Rheological measurements were performed at $50^{\circ} \mathrm{C}$, with a Rheomat 30 viscosimeter, equipped with an O-type coaxial cylindrical chamber (Contraves, Zurich, Switzerland). Viscosities were registered at shear rates $(\gamma)$ from $12.9-953.6 \mathrm{~s}^{-1}$.

\section{RESULTS}

\section{Physical properties of whey retentates}

\section{Volume of precipitated fraction.}

Microscope observation of pretreated $R_{2.5}$ and $R_{4.0}$ showed large aggregates surrounded by a translucent liquid phase. In pretreated $R_{5.5}$, the aggregates coalesced and filled the whole volume. There was no translucent phase. The aggregates in pretreated $R_{2.5}$ and $R_{4.0}$ tended to sediment leading to a clear supernatant. The sedimentation was complete after $1 \mathrm{~h}$ standing. The volume fraction occupied by the precipitate increased with concentration of retentate: 0.86 for $R_{2.5}$, and 0.96 for $R_{4.0}$. Extrapolation of the results gives 1.00 for $R_{4.5}$. This means no more sedimentation of the aggregated matter would occur at VCR $>4.5$.

\section{Particle size}

The aggregates in pretreated $R_{2.5}$ were 7$10 \mu \mathrm{m}$ in size, as determined by microscope observation. These appeared to be constituted of smaller granulated material $<0.5-1 \mu \mathrm{m}$.

The detection of smaller particles in wheys and estimation of their mean diameter by quasi-elastic light diffusion is reported in table II. Initial UF whey retentate, its supernatant and pretreated UF whey retentate before any separation all showed particles of 206-209 nm, whereas in a second group of particles the size was different in initial retentate $(1460 \mathrm{~nm})$, its supernatant $(1050 \mathrm{~nm})$ and the non-separated pretreated retentates $(726 \mathrm{~nm})$. These particles were found in neither the 2 microfiltrates nor the supernatant of pretreated retentate, where only smaller particles of 4 , 6 and $12 \mathrm{~nm}$ were detected.

\section{Rheological measurements}

The viscosity of whey retentates versus shear rate is shown in figure 1 . The viscosity of non-pretreated retentates $(\mathrm{Ca}=0.4$ $\mathrm{g} \cdot \mathrm{kg}^{-1}$ ) was only slightly affected by VCR: $\mu=0.94 \mathrm{mPa} \cdot \mathrm{s}$ for $R_{2.5}$ and $\mu=1.01$ $\mathrm{mPa} \cdot \mathrm{s}\left(\gamma=953.6 \mathrm{~s}^{1}\right)$ for $R_{5.5}$. Pretreated retentates showed a viscosity increase compared to non-pretreated ones. The increase was related to retentate VCR and to $\mathrm{Ca}$ level, up to a maximum (results not shown). Moreover, a shear thinning behavior was observed with these samples (fig 1). Supernatants of pretreated retentates had a viscosity close to that of the nonpretreated initial ones. As an example, the viscosity of $R_{2.5}$ was $\mu=0.89 \mathrm{mPa} \cdot \mathrm{s}$ and that of pretreated supernatant $\mu=0.85$ $\mathrm{mPa} \cdot \mathrm{s}\left(\gamma=953.6 \mathrm{~s}^{-1}\right)$.

\section{Fractionation by centrifugation and microfiltration}

\section{Biochemical studies}

The fractionation obtained with microfiltration was extensively studied with 1 of the 
Table II. Size of small particles $(<2000 \mathrm{~nm})$ in $R_{2.5}$. Incidence of separation process, centrifugation (CF) or microfiltration (MF), and of calcium pretreatment (non-pretreated $R_{2.5}$ or pretreated $\left.R_{2.5-1.3}\right)^{*}$. Taille des petites particules $\left(<2000 \mathrm{~nm}\right.$ ) dans le $R_{2,5}$. Influence du procédé de séparation (centrifugation, $C F$, ou microfiltration MF) et du prétraitement du rétentat (non prétraité, $R_{2,5}$, prétraité, $R_{2,5-1,3}$ ).

\begin{tabular}{|c|c|c|c|c|c|c|}
\hline & \multicolumn{2}{|c|}{ Initial } & \multicolumn{2}{|c|}{ Supernatant CF } & \multicolumn{2}{|c|}{ Microfiltrate MF } \\
\hline & $R_{2.5}$ & $R_{2.5-1.3}$ & $R_{2.5}$ & $R_{2.5-1.3}$ & $R_{2.5}$ & $R_{2.5-1.3}$ \\
\hline Avd & 209 & 206 & 208 & 12 & 6 & 4 \\
\hline SD & 100 & 100 & 93 & 3 & 2 & 2 \\
\hline$\%$ & 26 & 35 & 51 & 95 & 99 & 100 \\
\hline Avd & 1460 & 726 & 1050 & & & \\
\hline SD & 200 & 98 & 200 & & & \\
\hline$\%$ & 72 & 47 & 49 & & & \\
\hline
\end{tabular}

Average diameter (Av d) in nm; SD: standard deviation; \% percentage by weight.

Av d: diamètre moyen en $\mathrm{nm}$. SD: écart type; \%: pourcentage en poids.

retentates, $R_{25}$. Comparison was made between centrifugation and microfiltration applied to either non-pretreated $\left(R_{2.5}\right)$ or pretreated retentate $\left(R_{2.5-1.3}\right)$. The amount of the main constituents in initial retentates and their supernatants and microfiltrates are reported in table III.

Centrifugation of the initial retentate had little effect on the OD (1.400/1.100). When combined with pretreatment, an OD decrease to 0.320 was obtained; this value is in good agreement with previous results (Pierre et al, 1992). Microfiltration resulted in a more drastic OD decrease, to $0.006-$ 0.010 , with pretreated as well as with nonpretreated retentates.

Centrifugation of non-pretreated $R_{2.5}$ resulted in little or no alteration of component contents. Any of the 3 other procedures (CF of pretreated $R_{2.5-1.3}$, MF of $R_{2.5}$ and $R_{2.5-1.3}$ ) led to a highly significant decrease of component concentration. TNM in centrifuged pretreated retentates and in microfiltered non-treated retentates was $0.88-0.89$ times its initial value. A lower proportion (0.68) was obtained in micro- filtrate of $R_{2.5-1.3}$. On the other hand, the best removal of lipids and phospholipids was performed in this particular case $(0.06$ $\mathrm{g} \cdot \mathrm{kg}^{-1}$ and non-detectable content).

The concentration of proteinic constituents is reported in figure 2. Compared with

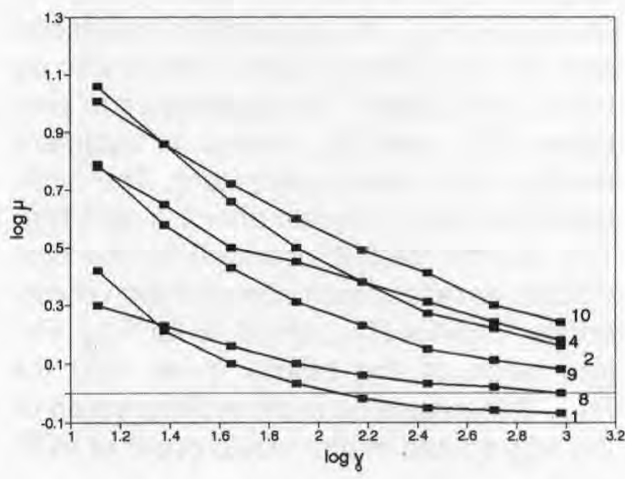

Fig 1. Whey UF retentates viscosity $(\mu)$ versus shear rate $(\mathrm{g}): \mathrm{R}_{2.5}(1) ; \mathrm{R}_{2.5-1.3}(2) ; \mathrm{R}_{2.5-3.3}$ (4); $R_{5.5}(8) ; R_{5.5-1.3}(9) ; R_{5.5-3.3}(10)$.

Viscosité des rétentats UF de lactosérum $(\mu)$ en fonction de la vitesse de cisaillements $(g): R_{2,5}$ (1); $R_{2,5-1,3}$ (2); $R_{2,5-3,3}$ (4); $R_{5,5}$ (8); $R_{5,5-1,3}$ (9); $R_{5,5-3,3}(10)$. 
Table III. Composition of initial $R_{2.5}$ and its supernatants and microfiltrates obtained by centrifugation (CF) or microfiltration (MF) or pretreated $\left(R_{2.5-1.3}\right)$ or non-pretreated $\left(R_{2.5}\right)$ retentate $\mathrm{g} \mathrm{kg}^{-1}$. Composition du rétentat initial $R_{2,5}$ et des surnageants et microfiltrats obtenus par centrifugation (CF) ou microfiltration (MF) du rétentat prétraité $\left(R_{2,5-1,3}\right)$ ou non prétraité $\left(R_{2,5}\right) \mathrm{g} \cdot \mathrm{kg}^{-1}$.

\begin{tabular}{|c|c|c|c|c|c|}
\hline & \multirow[t]{2}{*}{ Initial $R_{2.5}$} & \multicolumn{2}{|c|}{ Supernatant CF } & \multicolumn{2}{|c|}{ Microfiltrate MF } \\
\hline & & $R_{2.5}$ & $R_{2.5-1.3}$ & $R_{2.5}$ & $R_{2.5-1.3}$ \\
\hline OD & 1.400 & 1.100 & 0.320 & 0.010 & 0.006 \\
\hline Lactose & 48.6 & 48.7 & 48.2 & 43.7 & 40.7 \\
\hline $\mathrm{P}$ & 0.459 & 0.425 & 0.175 & 0.393 & 0.115 \\
\hline $\mathrm{Ca}$ & 0.393 & 0.337 & 0.667 & 0.302 & 0.564 \\
\hline Total lipids & 1.14 & 1.14 & 0.25 & 0.11 & 0.06 \\
\hline Phospholipids & 0.22 & 0.22 & 0.10 & 0.02 & 0.00 \\
\hline TNM & 18.8 & 18.8 & 16.7 & 16.5 & 12.8 \\
\hline Experimental TNMr & 1.00 & 1.00 & 0.89 & 0.88 & 0.68 \\
\hline
\end{tabular}

OD: optical density; TNM: total nitrogen matter; TNMr: total nitrogen matter recovery.

initial $R_{2.5}$, there were few differences in the NPN, CMP and ala levels in supernatants and microfiltrates. On the contrary, the $\beta$ lg content was greatly reduced, particularly in the microfiltrate of $R_{2.5-1.3}: 5.8$ $\mathrm{g} \cdot \mathrm{kg}^{-1}$ instead of $8.2 \mathrm{~g} \cdot \mathrm{kg}^{-1}$ in initial $R_{2.5}$ (fig 2), ie a retention equal to 0.29 . On the other hand, the other non-specifically analyzed components were reduced from 4.40 to $2.6 \mathrm{~g} \cdot \mathrm{kg}^{-1}$ in supernatants of $R_{2.5-1.3}$

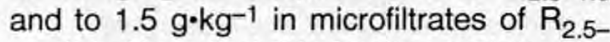
1.3. It is likely that this fraction mainly contained the high molecular mass proteins, mainly immunoglobulins, bovine serum albumin and lactoferrin.

The composition of samples was further assessed by electrophoresis which showed:

i) a lower level of high molecular mass proteins in both microfiltrates of $R_{2.5}$ and $R_{2.5}$ 1.3 ;

ii) no proteose peptone $\mathrm{PP}_{3}$ or $\mathrm{PP}_{5}$ in both microfiltrates and the supernatant of $R_{2.5}$ ${ }_{1.3}\left(\mathrm{PP}_{3}=\right.$ milk fat globule membrane fraction and $P P_{5}=\beta$-casein 1-106 fraction); iii) no $\mathrm{PP}_{8}\left(\mathrm{PP}_{8}=\beta\right.$-casein 26-106 fraction) in the microfiltrate or supernatant of $R_{2.5-1.3}$. Presence of $\mathrm{PP}_{8}$ in microfiltrate or supernatant of non-pretreated $R_{2.5}$.

Maximum TNMr calculated from these results, as described in Materials and Methods, were in the same range, $0.92-$

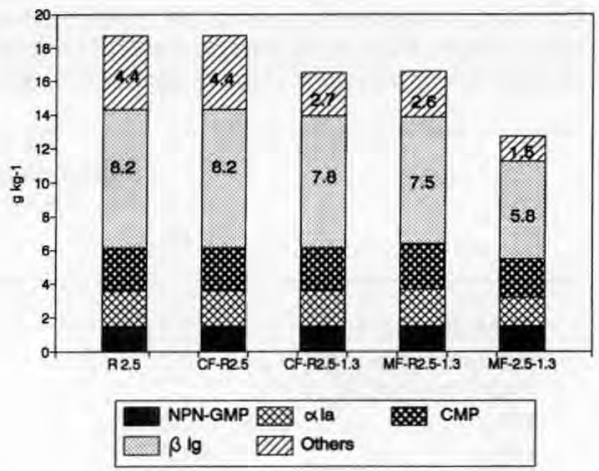

Fig 2. Proteinic constituents in microfiltrates (MF) and supernatants (CF) of $R_{2.5}$ and $R_{2.5-1.3}$. Constitutants protéiques des microfiltrats (MF) et de surnageants (CF) du $R_{2,5}$ et $R_{2,5-1,3}$. 
0.88 , with the 2 microfiltrates and the supernatant of $R_{2.5-1.3}$ (table IV).

\section{Incidence of protein concentration and calcium pretreatment on microfiltrate composition}

The composition of microfiltrates obtained from retentates with various volume concentration factors and pretreated with different calcium levels was reported in table $\mathrm{I}$.

OD values of microfiltrates $(0.010<O D$ $<0.048$ ) showed no incidence of whey pretreatment. A slight but significant effect of protein concentration on $\mathrm{OD}$ was shown: average OD was 0.041 with $R_{5.5}$ and 0.011 with $R_{2.5}$ and $R_{4.0}$.

TNMr also depended on protein concentration. With no calcium pretreatment, TNMr values of 0.88 and 0.83 were obtained with $R_{2.5}$ and $R_{5.5}$, respectively, showing a slight transmission decrease at higher protein concentration.

Pretreating whey UF retentate resulted in a TNMr decrease: $0.65-0.66$ with $R_{2.5}$ and $R_{4.0}$ and $0.42-0.41$ with $R_{5.5}$. Other constituents (calcium, phosphorus) and $\mathrm{pH}$ were at the same level in the various microfiltrates.

\section{Hydraulic performance}

The recording of hydraulic parameters $\left(R_{f}\right.$, TP) versus time of microfiltration allowed the calculation of $R_{f} / R_{m}$ for all runs. As an example, figure 3 reports the results for $R_{2.5}$ and $R_{5.5}$. With $R_{5.5-1.3}$ and $R_{5.5-3.3}$, a progressive increase in $R_{f} / R_{m}$ with time was observed.

The corresponding $R_{f} / R_{m}$ were calculated from values of $R_{f}$ and TP collected after 60 min microfiltration (table V). When plotted against $R_{m}$ (fig 4 ), significantly higher values appeared for runs 9 and $10\left(R_{5.5-}\right.$ 1.3 and $R_{5.5-3.3}$ ), all other values being lower and showing neither treatment effect nor residual incidence of $R_{m}$ after correction. The higher values of $R_{f} / R_{m}$ in runs 9 and 10 were related to retentate concentration (VCR), as shown in figure 5. Calcium level had no effect (fig 5).

Table IV. Calculation of maximum TNMr ( $\mathrm{TNMr}_{\max }$ ) according to the fractionation observed for proteinic constituents in $R_{2.5}$ and to their quantification in $\mathrm{g} \mathrm{kg}^{-1}$ from Walstra and Jenness (1984).

Calcul du rendement maximal en matière azotée totale ( $T N M r_{\text {max }}$ ) pour les différents procédés étudiés, compte tenu d'une part du fractionnement observé pour les constituants protéiques, d'autre part, de leur teneur moyenne dans le lactosérum $\left(g \cdot \mathrm{kg}^{-1}\right)$ estimée d'après Walstra et Jenness (1984).

\begin{tabular}{|c|c|c|c|c|c|}
\hline & & \multicolumn{2}{|c|}{ Supernatant $C F$} & \multicolumn{2}{|c|}{ Microfiltrate MF } \\
\hline & & $R_{2.5}$ & $R_{2.5-1.3}$ & $R_{2.5}$ & $R_{2.5-1.3}$ \\
\hline \multirow[t]{5}{*}{1} & $\begin{array}{l}\text { TNM of initial } R_{2.5} \\
\text { Retained material } \\
\text { (level in initial } R_{25} \text { ) }\end{array}$ & 18.8 & 18.8 & 18.8 & 18.8 \\
\hline & $\mathrm{PP}_{3}$ & 0 & 0.6 & 0.6 & 0.6 \\
\hline & $\mathrm{PP}_{8}^{3}$ & 0 & 0.3 & 0 & 0.3 \\
\hline & $\mathrm{PP}_{5}^{\circ}$ & 0 & 0.6 & 0.6 & 0.6 \\
\hline & $\mathrm{Blg}^{5}$ & 0 & 0 & 0.8 & 0.8 \\
\hline 2 & Total retained & 0 & 1.5 & 2.0 & 2.3 \\
\hline 3 & $\mathrm{TNM}_{\max } \mathrm{g} \cdot \mathrm{kg}^{-1} 1-2$ & 18.8 & 17.3 & 16.8 & 16.5 \\
\hline 4 & $\mathrm{TNMr}_{\max } 3 / 1$ & 1.00 & 0.92 & 0.89 & 0.88 \\
\hline
\end{tabular}




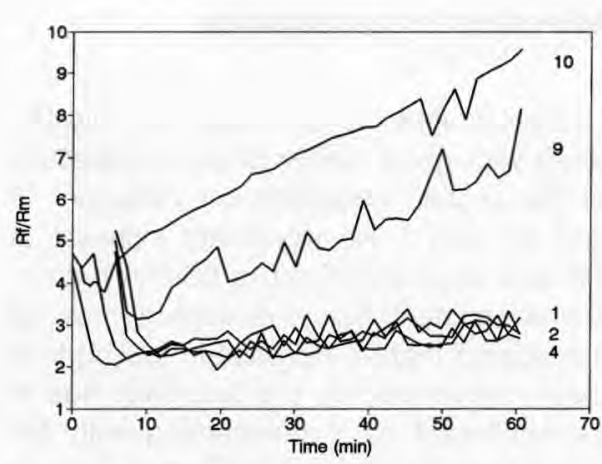

Fig 3. Variation of $R_{f} / R_{m}$ versus time of microfiltration. Incidence of volume concentration ratio and pretreatment: $R_{2.5}(1) ; R_{2.5-1.3}(2) ; R_{2.5-3.3}$ (4); $R_{5.5-1.3}(9) ; R_{5.5-3.3}(10)$.

Évolution de $R_{1} R_{m}$ en fonction du temps de microfiltration. Influence du facteur de concentration volumique (VCR) du rétentat et du prétraitement : $R_{2,5}$ (1); $R_{2,5-1,3}$ (2); $R_{2,5-3,3}$ (4); $R_{5,5-1,3}$ (9): $R_{5,5-3,3}(10)$.

\section{DISCUSSION}

\section{Clarification efficiency}

Microfiltration was more efficient than centrifugation for whey clarification. Very low $O D$ values were observed in microfiltrates, even with no $\mathrm{Ca}$ pretreatment $(0.010$ 0.041 ), while centrifugation, even combined with a pretreatment gave higher $O D$ values; for supernatants produced under optimal conditions with $R_{2.5}$ and $R_{5.5}$ typical OD values would be $0.180-0.380$. The difference in efficiency between the 2 processes may be explained by the particle sizes measured in retentates. Particles ranging from 200 to $1500 \mathrm{~nm}$ in diameter were present in initial retentates. Conditions applied during centrifugation were not

Table V. Microfiltration of whey ultrafiltration (UF) retentates. Initial membrane hydraulic resistance $R_{m}$ and fouling characteristics $R_{f}, R_{r f}$ and $R_{i f}$ (see Materials and Methods) .

Microfiltration des rétentats UF de lactosérum. Résistance hydraulique initiale de la membrane propre, $R_{m}$, et caractéristiques du colmatage, $R_{f} R_{r f}$ et $R_{i f}$ (Material and Methods)* .

\begin{tabular}{|c|c|c|c|c|c|c|c|}
\hline \multirow{2}{*}{$\begin{array}{l}\text { Run } \\
N^{\circ}\end{array}$} & \multirow[t]{2}{*}{ Retentate } & \multicolumn{2}{|c|}{ Microfiltration of water } & \multicolumn{4}{|c|}{ Microfiltration of whey UF retentate } \\
\hline & & $\begin{array}{l}J_{w} \\
l \cdot h^{-1} \cdot m^{-2}\end{array}$ & $\begin{array}{l}R_{m} \\
10^{12} m^{1}\end{array}$ & $\begin{array}{l}\text { TP60 } \\
\mathrm{MPa}\end{array}$ & $\begin{array}{l}R_{f} \\
10^{12} \mathrm{~m}^{1}\end{array}$ & $\begin{array}{l}R_{r^{12}} \\
0^{12} \mathrm{~m}^{1}\end{array}$ & $\begin{array}{l}R_{i f} \\
10^{12} \mathrm{~m}^{-1}\end{array}$ \\
\hline 1 & $\mathrm{R}_{2.5}$ & 428 & 1.57 & 0.09 & 5.9 & 0.6 & 5.3 \\
\hline 2 & $\mathrm{R}_{2.5-1.3}$ & 483 & 1.39 & 0.07 & 4.5 & 3.2 & 1.3 \\
\hline 3 & $R_{2.5-1.3}$ & 439 & 1.53 & 0.06 & 4.0 & 0.7 & 3.3 \\
\hline 4 & $R_{2.5-3.3}$ & 487 & 1.37 & 0.06 & 3.6 & 2.4 & 1.2 \\
\hline 5 & $\mathrm{R}_{4.0-2.3}$ & 455 & 1.47 & 0.06 & 3.8 & 1.5 & 2.3 \\
\hline 6 & $R_{4.0-2.3}$ & 433 & 1.55 & 0.05 & 4.3 & 1.8 & 2.5 \\
\hline 7 & $\mathrm{R}_{4.0-2.3}$ & 667 & 1.00 & 0.03 & 2.7 & 1.4 & 1.3 \\
\hline 8 & $\mathrm{R}_{5.5}$ & 512 & 1.31 & 0.05 & 4.4 & 1.8 & 2.6 \\
\hline 9 & $R_{5.5-1.3}$ & 473 & 1.41 & 0.15 & 10.4 & 9.4 & 1.0 \\
\hline \multirow[t]{4}{*}{10} & $\mathrm{R}_{5.5-3.3}$ & 534 & $1.25^{\circ}$ & 0.15 & 10.8 & 7.6 & 3.2 \\
\hline & $\overline{\mathrm{m}}$ & 491 & 1.38 & & & & \\
\hline & SD & 71 & 0.17 & & & & \\
\hline & SE & & & 0.02 & 1.4 & 0.1 & 0.9 \\
\hline
\end{tabular}

* TP: transmembrane pressure. SD: standard deviation; $\bar{m}$ : mean; SE: standard error. 
efficient enough to allow their sedimentation. Sedimentation was achieved after $\mathrm{Ca}$ pretreatment, which formed aggregates sized 7-10 $\mu \mathrm{m}$. Using a microfiltration membrane with $200 \mathrm{~nm}$ mean pore size, total retention of the native individual particles $(>200 \mathrm{~nm}$ ) took place, even with no pretreatment.

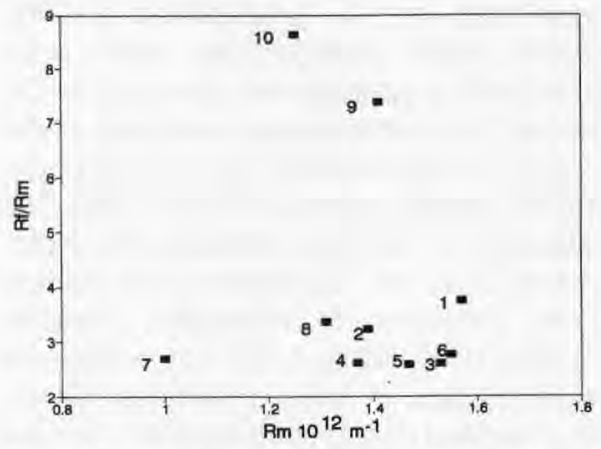

Fig 4. Overall fouling resistance $R_{p} / R_{m}$ after 60 $\min$ MF run $\left(\mathrm{J}=60 \mathrm{l} \cdot \mathrm{h}^{-1} \cdot \mathrm{m}^{-2}\right)$ versus initial hydraulic resistance, $R_{m}$ with retentate-treated feeds and numbered as in tables $I$ and $V$.

Résistance de colmatage total $R / R_{m}$ après 60 min de microfiltration des rétentats $(J=60 / \cdot h-1$ $\cdot-m^{-2}$ ) en fonction de la résistance initiale de la membrane propre, $R_{m}$. Pour la composition et le prétraitement des rétentats, les chiffres renvoient aux tableaux $/$ et $V$.

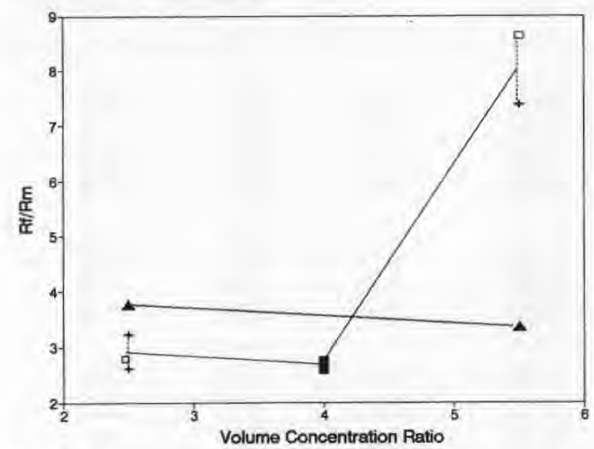

Fig 5. $R_{f} / R_{m}$ versus volume concentration ratio of retentate: $R \times(\mathbf{A})$; $R x-1.3(+) ; x_{-2.3}(\mathbf{D}) ; x_{-3.3}$ (口).

$R, R_{m}$ en fonction du facteur de concentration volumique (VCR) du rétentat : $R x(\mathbf{\Delta})$; $R x-1,3$ $(+) ; R x_{-2,3}(\mathbf{D}) ; R x_{-3,3}(\square)$.

\section{Microfiltration performance}

Non-pretreated wheys could be microfiltered with good performance, irrespective of the protein concentration between 18 and $40 \mathrm{~g} \cdot \mathrm{kg}^{-1}$. No significant increase in TP was observed during a 60-min run under a constant flux, therefore it may be considered that no increase in fouling took place. Nevertheless, the feasibility has to be confirmed by experimenting with MF runs of several hours. No effect of $\mathrm{Ca}$ concentration was observed. Low amplitude effects of some parameters (VCR, calcium addition) might have been masked by the high standard deviation in $R_{m}$ values (table $V: 0.17 \times 10^{12} \mathrm{~m}^{-1}$ ). Nevertheless, $R_{f} / R_{m}$ calculated after 60 min of microfiltration did not depend significantly on $R_{m}$ values (fig 5). The threshold shape effect of VCR (between 4.0-5.5) on $R_{f}$, could be explained according to 2 hypotheses.

Pretreatment requires a $\mathrm{pH}$ increase from 6.7 to 7.3 . This obviously might favor the formation of insoluble $\mathrm{Ca}$ phosphate from the soluble phase, and its precipitation on or in the membrane. If so, low performance would have been obtained with pretreated $R_{2.5}$ and $R_{4.0}$ and not only with pretreated $R_{5.5}$, as observed. In addition, the 60 -min run is likely to be too short compared with the requested lag time for salt precipitation in our MF conditions. This hypothesis must also be validated with longer runs.

On the other hand, we had to question the effect of physical properties of pretreated $R_{5.5}$ on MF performance. In this product a stable continuous network was observed throughout the whole volume, arising from aggregated colloidal material concentrated enough to form interparticulate binding of low strength. This structure may be the reason why shear thinning properties were observed. The viscosity of these products was consequently dependent on flow rate. 
In microfiltration, with tubular M14 membrane, the tangential flow rate was $6 \mathrm{~m} * \mathrm{~s}^{-1}$, which corresponds to a turbulent flow, owing to the membrane configuration. Close to the membrane, the flow velocity drastically decreased and a higher viscosity for the shear thinning product has to be considered. This might promote enhanced material deposition on and/or in the membrane. Higher values for $R_{r}$ (7.6 and $9.4 x$ $10^{12} \mathrm{~m}^{-1}$, table V) were effectively observed in this case, corresponding to higher membrane surface fouling.

From a hydraulic point of view, the increase in membrane resistance to microfiltrate transfer can be assimilated to a pore size reduction and the correponding mean pore diameter can be calculated from Poiseuille's law. In the early stages of the runs, ie at $6 \mathrm{~min}$, mean pore diameter was found to be $190 \mathrm{~nm}$. After a 60-min run, it was found to be $182 \mathrm{~nm}$ for $\operatorname{TP}_{60}=0.058$ $\mathrm{MPa}$ and $113 \mathrm{~nm}$ for $\mathrm{TP}_{60}=0.15 \mathrm{MPa}$ (pretreated $R_{5.5}$ ), compared with $200 \mathrm{~nm}$ for the clean membrane on water.

\section{Protein recovery}

Microfiltration of non-pretreated wheys was as efficient as centrifugation for proteinic recovery (TNMr) and allowed $\mathrm{TNMr}_{\max }$ to be reached. Microfiltration of pretreated retentates showed lower TNMr. An assessment of nitrogen matter retention was given by the difference: $\mathrm{TNMr}_{\max }-\mathrm{TNMr}$. This was $0.89-0.65=0.24$ for $R_{2.5}$ or $R_{4.0}$, and $0.89-0.41=0.48$ for $R_{5.5}$ from data in table I.

The individual protein quantification in $R_{2.5}$ microfiltrates (fig 2) showed that low $\mathrm{TNMr}$ are due to retention of not only high molecular mass proteins, but also ala and especially $\beta \mathrm{lg}(0.29)$ although its molecular mass is low ( $\beta \mathrm{gg}$ is at $\mathrm{pH} 7.0$ as a dimer, ie $36 \mathrm{kDa})$. As $\beta \mathrm{lg}$ is the main protein in whey and its retention $(0.29)$ was in the same range as TNM retention in pretreated $R_{2.5}$ (0.24), we used it as a model for explaining whey protein permeation.

Theoretical retention of $\beta \mathrm{lg}$ can be calculated according to Ferry's law. The diameter of the $\beta \mathrm{lg}$ dimer is estimated as 3.9 $\mathrm{nm}$ (McKenzie, 1971) with $2 \mathrm{~nm}$ more because of hydration and electrical double layer (Hiemenz, 1986) leading to $5.9 \mathrm{~nm}$ size. From fouled membrane resistance observations, the apparent mean pore size of the membrane after $60 \mathrm{~min}$ microfiltration is $182 \mathrm{~nm}\left(\mathrm{TP}_{60}=0.058 \mathrm{MPa}\right)$ and $113 \mathrm{~nm}\left(\mathrm{TP}_{60}=0.15 \mathrm{MPa}\right)$ with $\mathrm{R}_{5.5-1.3}$ and $R_{5.5-3.3}$, respectively. These pore sizes give theoretical retention values of around 0.01 . The experimental retention is of the same order of magnitude when microfiltering whey UF retentates with no pretreatment, but much higher values were assessed with pretreated feeds. Consequently, in the latter case, either Blg particle size or apparent pore size is different.

To get $\beta$ ig retention of $0.24\left(R_{2.5}\right)$ and $0.48\left(R_{5.5}\right)$ we use Ferry's law to calculate that $\beta \mathrm{lg}$ particles would be $50 \mathrm{~nm}$ in size. But particle size determination in whey retentates did not show such values.

On the other hand, assuming Big remained at its native size, experimental retention and Ferry's law enable calculation of a mean membrane pore size of 22 and $14 \mathrm{~nm}$, when microfiltering pretreated $R_{2.5}$ and $R_{5.5}$, respectively. This result does not fit previously discussed hydraulic results.

There is obviously a discrepancy between protein permeation results and hydraulic results. Whey premeation performance remained good, as shown through low TP, while protein recovery was poor, as with a fouled membrane. We can assume that microfiltering pretreated wheys, colloidal aggregates block the larger pores of the membrane, dividing the initial pores into smaller sized pores. The smooth retic- 
ulum obtained still remains highly hydrophilic, and consequently, permeable to water and microsolutes. This preserves the hydraulic properties of the membrane. In contrast, protein macromolecules would be slowed down in the flux by the reticulum and eventually build up inside the MF membrane pores.

\section{CONCLUSION}

Microfiltration was a useful tool to clarify non-pretreated whey UF retentates (VCR < 5.5). Pretreatment of UF whey retentates appears detrimental. It reduces TNM recovery of all the retentates and decreases hydraulic performance of VCR 5.5 retentates. The reason for this was not elucidated.

Clarification efficiency, as measured by $O D$ of the resulting product, was higher with MF $(0.010<O D<0.050)$ than with CF associated with pretreatment $(0.180<$ $\mathrm{OD}<0.380$ ). However, TNM recoveries obtained by MF of non-treated retentates were identical to those obtained by CF of treated retentates $(\mathrm{TNMr}=0.89$ ).

Present results were obtained from 1-h MF runs. It would be interesting to test if they remain valid for longer runs, in the range of several hours, to approach plant working conditions.

\section{ACKNOWLEDGMENTS}

We thank $J$ Fauquant and $M$ Piot who performed whey ultrafiltration. Improvements of the manuscript by $\mathrm{JL}$ Maubois are gratefully acknowledged.

\section{REFERENCES}

Andrews AT (1983) Proteinases in normal bovine milk and their action on caseins. J Dairy Res 50, 45-55
Baumy JJ, Gestin L, Fauquant J, Boyaval E, Maubois JL (1990) Technologie de purification des phospholipides du lactosérum. Process 1047, 29-33

Daufin G, Radenac JF, Gésan G, Kerhervé FL, Le Berre O, Michel F, Merin U (1993) A novel rig design for ultra- and microfiltration experiment. Sep Sci Technol 28, 1635-1642

de Wit JN, Klarenbeek G, de Boer R (1978) A simple method for whey clarification. 20th Int Dairy Congr, Brief Commun 919-920

Fauquant J, Vieco E, Brulé G, Maubois JL (1985a) Clarification of sweet whey by thermocalcic aggregation of the residual fat. Lait $65,1-20$

Fauquant J, Pierre A, Brulé G (1985b) Clarification of acid casein whey. Tech Lait 1003, 3741

FIL-IDF (1982) Determination of total phosphorus content in cheese. Standard $n^{\circ} 33 B$

Folch J, Lees MB, Sloane-Stanley GH (1957) A simple method for the isolation and purification of the total lipids from animal tissues. J Biol Chem 226, 497-509

Gésan G, Merin U, Daufin G, Maugas JJ (1993a) Performance of an industrial crossflow microfiltration plant for clarifying rennet whey. Neth Milk Dairy J 47, 121-135

Gésan G, Daufin G, Merin U, Labbé JP, Quemerais $A$ (1993b) Fouling during constant flux crossflow microfiltration of pretreated whey. Influence of transmembrane pressure gradient. J Membrane Sci 80, 131-145

Hiemenz PC (1986) The electrical double layer. In: Principle of colloïd and surface chemistry. 2nd ed (Heimenz PC, ed) M Dekker Inc, NY, 677-731

Lee DN, Merson RL (1976) Prefiltration of cottage cheese whey to reduce fouling of ultrafiltration membranes. J Food Sci 41, 403-410

Leseigneur A, Gandemer G, Marion D (1989) Fractionnement en classes des lipides alimentaires par HPLC à l'aide d'un détecteur à diffusion de lumière. In: Actes du Congrès International Chevreul pour l'Étude des corps gras T1 Etig 311-318

McKenzie HA (1971) Milk proteins, chemistry and molecular biology, vol II, Academic Press NY

Maubois JL, Pierre A, Fauquant J, Piot M (1987) Industrial fractionation of main whey proteins. Bull Int Dairy Fed 212, 154-159 
Maugas JJ, Daufin G (1992) Étude critique d'une installation industrielle de microfiltration et ultrafiltraton tangentielle pour la production de concentrés de protéines de lactosérum de haute pureté. Ind Alim Agric 109, 687-691

Pearce RJ, Marshall SC, Dunkerley JA (1992) Reduction of lipids in whey protein concentrates by microfiltration. Effect on functional properties. Int Dairy Fed (special issue) 9201, 118-129

Pierre A, Le Graet Y, Fauquant J, Piot M, Durier C, Kobilinsky A (1992) Optimization of physicochemical factors for whey clarification. Lait 72, 405-420
Rinn JC, Morr CV, Seo A, Surak JG (1990) Evaluation of 9 semi-pilot scale whey pretreatment modification for producing whey protein concentrate. J Food Sci 55, 510-515

Rowland SJ (1938) The determination of the nitrogen distribution in milk. J Dairy Res 9, 42-46

Surel O (1993) Lipides et microfiltration : contribution à la compréhension des mécanismes de transfert. Thesis, ENSAR, Rennes, France

Walstra P, Jenness R (1984) Dairy Chemistry and Physics. John Wiley and Sons, NY

Wasen I, Lehmann H Westfalia Separator (1989) Process for phospholipids removal in whey. Fr Patent 2625649 A1 